\title{
A generalization for the best proximity point of Geraghty-contractions
}

\author{
Nurcan Bilgili', Erdal Karapınar ${ }^{2 *}$ and Kishin Sadarangani ${ }^{3}$
}

\section{"Correspondence:}

erdalkarapinar@yahoo.com;

ekarapinar@atilim.edu.tr

${ }^{2}$ Department of Mathematics,

Atilim University, Incek, Ankara 06836, Turkey

Full list of author information is

available at the end of the article

\begin{abstract}
In this paper, we introduce the notion of Geraghty-contractions and consider the related best proximity point in the context of a metric space. We state an example to illustrate our result.

MSC: $47 \mathrm{H} 10 ; 54 \mathrm{H} 25 ; 46 \mathrm{~J} 10 ; 46 \mathrm{~J} 15$
\end{abstract}

\section{Introduction and preliminaries}

Fixed point theory and best proximity theory are very important tools in nonlinear functional analysis. These related research areas have wide application potential in various branches of mathematics and different disciplines such as economics, engineering. One of the most impressive results in this direction, known as the Banach contraction mapping principle, was given by Banach: Every contraction on a complete metric space has a unique fixed point. This celebrated result has been generalized in several ways in various abstract spaces. In particular, one of the interesting generalizations of the Banach contraction mapping principle was given by Geraghty [1].

Theorem 1 (Geraghty [1]) Let $(X, d)$ be a complete metric space and let $T: X \rightarrow X$ be an operator. Suppose that there exists $\beta:[0, \infty) \rightarrow[0,1)$ satisfying the condition

$$
\beta\left(t_{n}\right) \rightarrow 1 \text { implies } t_{n} \rightarrow 0 .
$$

If $T$ satisfies the following inequality:

$$
d(T x, T y) \leq \beta(d(x, y)) d(x, y) \quad \text { for any } x, y \in X
$$

then Thas a unique fixed point.

It is clear that some mapping on a complete metric space has no fixed point, that is, $d(x, T x)>0$ for all $x \in X$. In this case, it is natural to ask the existence and uniqueness of the smallest value of $d(x, T x)$. This is the main motivation of a best proximity point. This research subject has attracted attention of a number of authors; see, e.g., [1-19].

First we recall fundamental definitions and basic results in this direction.

Let $A$ and $B$ be nonempty subsets of a metric space $(X, d)$. A mapping $T: A \rightarrow B$ is called a $k$-contraction if there exists $k \in[0,1)$ such that $d(T x, T y) \leq k d(x, y)$ for any $x, y \in A$. Notice that the $k$-contraction coincides with the Banach contraction mapping principle if

(c) 2013 Bilgili et al.; licensee Springer. This is an Open Access article distributed under the terms of the Creative Commons Attribution License (http://creativecommons.org/licenses/by/2.0), which permits unrestricted use, distribution, and reproduction in any medium, provided the original work is properly cited. 
one takes $A=B$, where $A$ is a complete subset of $X$. A point $x^{*}$ is called the best proximity of $T$ if $d\left(x^{*}, T x^{*}\right)=d(A, B)$, where $d(A, B)=\inf \{d(x, y): x \in A, y \in B\}$.

Let $A$ and $B$ be two nonempty subsets of a metric space $(X, d)$. We denote by $A_{0}$ and $B_{0}$ the following sets:

$$
\begin{aligned}
& A_{0}=\{x \in A: d(x, y)=d(A, B) \text { for some } y \in B\}, \\
& B_{0}=\{y \in B: d(x, y)=d(A, B) \text { for some } x \in A\} .
\end{aligned}
$$

We denote by $F$ the set of all functions $\beta:[0, \infty) \rightarrow[0,1)$ satisfying the following property:

$$
\beta\left(t_{n}\right) \rightarrow 1 \text { implies } t_{n} \rightarrow 0 .
$$

Definition 2 (See [2]) Let $A, B$ be two nonempty subsets of a metric space $(X, d)$. A mapping $T: A \rightarrow B$ is said to be a Geraghty-contraction if there exists $\beta \in F$ such that

$$
d(T x, T y) \leq \beta(d(x, y)) \cdot[d(x, y)] \text { for any } x, y \in A .
$$

Very recently Raj $[10,11]$ introduced the notion of $P$-property as follows.

Definition 3 Let $(A, B)$ be a pair of nonempty subsets of a metric space $(X, d)$ with $A_{0} \neq \emptyset$. Then the pair $(A, B)$ is said to have the $P$-property if and only if for any $x_{1}, x_{2} \in A_{0}$ and $y_{1}, y_{2} \in B_{0}$,

$$
d\left(x_{1}, y_{1}\right)=d(A, B) \quad \text { and } \quad d\left(x_{2}, y_{2}\right)=d(A, B) \quad \Rightarrow \quad d\left(x_{1}, x_{2}\right)=d\left(y_{1}, y_{2}\right)
$$

Example 4 (See, e.g., [11]) Let $A$ be a nonempty subset of a metric space $(X, d)$. It is evident that the pair $(A, A)$ has the $P$-property. Let $(A, B)$ be any pair of nonempty, closed, convex subsets of a real Hilbert space $H$. Then $(A, B)$ has the $P$-property.

Theorem 5 (See [2]) Let $(A, B)$ be a pair of nonempty closed subsets of a complete metric space $(X, d)$ such that $A_{0}$ is nonempty. Let $T: A \rightarrow B$ be a continuous, Geraghty-contraction satisfying $T\left(A_{0}\right) \subseteq B_{0}$. Suppose that the pair $(A, B)$ has the P-property. Then there exists a unique $x^{*}$ in $A$ such that $d\left(x^{*}, T x^{*}\right)=d(A, B)$.

The subject of this paper is to generalize, improve and extend the results of Caballero, Harjani and Sadarangani [2]. For this purpose, we first define the notion of generalized Geraghty-contraction as follows.

Definition 6 Let $A, B$ be two nonempty subsets of a metric space $(X, d)$. A mapping $T$ : $A \rightarrow B$ is said to be a generalized Geraghty-contraction if there exists $\beta \in F$ such that

$$
d(T x, T y) \leq \beta(M(x, y)) \cdot[M(x, y)-d(A, B)] \text { for any } x, y \in A,
$$

where $M(x, y)=\max \{d(x, y), d(x, T x), d(y, T y)\}$. 
Remark 7 Notice that since $\beta:[0, \infty) \rightarrow[0,1)$, we have

$$
\begin{aligned}
d(T x, T y) & \leq \beta(M(x, y)) \cdot[M(x, y)-d(A, B)] \\
& <M(x, y) \quad \text { for any } x, y \in A \text { with } x \neq y
\end{aligned}
$$

where $M(x, y)=\max \{d(x, y), d(x, T x), d(y, T y)\}$.

\section{Main results}

We start this section with our main result.

Theorem 8 Let $(X, d)$ be a complete metric space. Suppose that $(A, B)$ is a pair of nonempty closed subsets of $X$ and $A_{0}$ is nonempty. Suppose also that the pair $(A, B)$ has the P-property. If a non-self-mapping $T: A \rightarrow B$ is a generalized Geraghty-contraction satisfying $T\left(A_{0}\right) \subseteq$ $B_{0}$, then there exists a unique best proximity point, that is, there exists $x^{*}$ in $A$ such that $d\left(x^{*}, T x^{*}\right)=d(A, B)$.

Proof Let us fix an element $x_{0}$ in $A_{0}$. Since $T x_{0} \in T\left(A_{0}\right) \subseteq B_{0}$, we can find $x_{1} \in A_{0}$ such that $d\left(x_{1}, T x_{0}\right)=d(A, B)$. Further, as $T x_{1} \in T\left(A_{0}\right) \subseteq B_{0}$, there is an element $x_{2}$ in $A_{0}$ such that $d\left(x_{2}, T x_{1}\right)=d(A, B)$. Recursively, we obtain a sequence $\left\{x_{n}\right\}$ in $A_{0}$ with the following property:

$$
d\left(x_{n+1}, T x_{n}\right)=d(A, B) \quad \text { for any } n \in \mathbb{N} .
$$

Due to the fact that the pair $(A, B)$ has the $P$-property, we derive that

$$
d\left(x_{n}, x_{n+1}\right)=d\left(T x_{n-1}, T x_{n}\right) \quad \text { for any } n \in \mathbb{N} \text {. }
$$

From (2.1), we get

$$
d\left(x_{n-1}, T x_{n-1}\right) \leq d\left(x_{n-1}, x_{n}\right)+d\left(x_{n}, T x_{n-1}\right)=d\left(x_{n-1}, x_{n}\right)+d(A, B) .
$$

On the other hand, by (2.1) and (2.2) we obtain that

$$
d\left(x_{n}, T x_{n}\right) \leq d\left(x_{n}, T x_{n-1}\right)+d\left(T x_{n-1}, T x_{n}\right)=d\left(x_{n}, x_{n+1}\right)+d(A, B) .
$$

Consequently, we have

$$
\begin{aligned}
M\left(x_{n-1}, x_{n}\right) & =\max \left\{d\left(x_{n-1}, x_{n}\right), d\left(x_{n-1}, T x_{n-1}\right), d\left(x_{n}, T x_{n}\right)\right\} \\
& \leq \max \left\{d\left(x_{n-1}, x_{n}\right), d\left(x_{n}, x_{n+1}\right)\right\}+d(A, B) .
\end{aligned}
$$

If there exists $n_{0} \in \mathbb{N}$ such that $d\left(x_{n_{0}}, x_{n_{0}+1}\right)=0$, then the proof is completed. In fact, due to (2.2), we have

$$
0=d\left(x_{n_{0}}, x_{n_{0}+1}\right)=d\left(T x_{n_{0}-1}, T x_{n_{0}}\right)
$$

which yields that $T x_{n_{0}-1}=T x_{n_{0}}$. Hence, equation (2.1) implies that

$$
d(A, B)=d\left(x_{n_{0}}, T x_{n_{0}-1}\right)=d\left(x_{n_{0}}, T x_{n_{0}}\right) .
$$


For the rest of the proof, we suppose that $d\left(x_{n}, x_{n+1}\right)>0$ for any $n \in \mathbb{N}$. Owing to the fact $T$ is a generalized Geraghty-contraction, we derive that

$$
\begin{aligned}
d\left(x_{n}, x_{n+1}\right) & =d\left(T x_{n-1}, T x_{n}\right) \\
& \leq \beta\left(M\left(x_{n-1}, x_{n}\right)\right)\left(M\left(x_{n-1}, x_{n}\right)-d(A, B)\right) \\
& <M\left(x_{n-1}, x_{n}\right)-d(A, B) .
\end{aligned}
$$

Then, by (2.3) and (2.6), we deduce that

$$
d\left(x_{n}, x_{n+1}\right)<M\left(x_{n-1}, x_{n}\right)-d(A, B) \leq \max \left\{d\left(x_{n-1}, x_{n}\right), d\left(x_{n}, x_{n+1}\right)\right\} .
$$

Suppose that $\max \left\{d\left(x_{n-1}, x_{n}\right), d\left(x_{n}, x_{n+1}\right)\right\}=d\left(x_{n}, x_{n+1}\right)$. Then we get that

$$
d\left(x_{n}, x_{n+1}\right)<d\left(x_{n}, x_{n+1}\right),
$$

a contradiction. As a result, we conclude that $\max \left\{d\left(x_{n-1}, x_{n}\right), d\left(x_{n}, x_{n+1}\right)\right\}=d\left(x_{n-1}, x_{n}\right)$ and hence

$$
M\left(x_{n-1}, x_{n}\right) \leq \max \left\{d\left(x_{n-1}, x_{n}\right), d\left(x_{n}, x_{n+1}\right)\right\}+d(A, B)=d\left(x_{n-1}, x_{n}\right)+d(A, B) .
$$

By (2.6), we get

$$
\begin{aligned}
d\left(x_{n}, x_{n+1}\right) & =d\left(T x_{n-1}, T x_{n}\right) \\
& \leq \beta\left(M\left(x_{n-1}, x_{n}\right)\right) d\left(x_{n-1}, x_{n}\right) \\
& <d\left(x_{n-1}, x_{n}\right)
\end{aligned}
$$

for all $n \in \mathbb{N}$. Consequently, $\left\{d\left(x_{n}, x_{n+1}\right)\right\}$ is a nonincreasing sequence and bounded below. Thus, there exists $L \geq 0$ such that $\lim _{n \rightarrow \infty}\left(d\left(x_{n}, x_{n+1}\right)\right)=L$. We shall show that $L=0$. Suppose, on the contrary, $L>0$. Then, by (2.8), we have

$$
\frac{d\left(x_{n+1}, x_{n+2}\right)}{d\left(x_{n}, x_{n+1}\right)} \leq \beta\left(M\left(x_{n}, x_{n+1}\right)\right) \leq 1
$$

for each $n \geq 1$. In what follows,

$$
\lim _{n \rightarrow \infty} \beta\left(M\left(x_{n}, x_{n+1}\right)\right)=1 .
$$

On the other hand, since $\beta \in F$, we conclude $\lim _{n \rightarrow \infty} M\left(x_{n}, x_{n+1}\right)=0$, that is,

$$
L=\lim _{n \rightarrow \infty} d\left(x_{n}, x_{n+1}\right)=0 .
$$

Since, $d\left(x_{n}, T x_{n-1}\right)=d(A, B)$ holds for all $n \in \mathbb{N}$ and $(A, B)$ satisfies the $P$-property, then, for all $m, n \in \mathbb{N}$, we can write, $d\left(x_{m}, x_{n}\right)=d\left(T x_{m-1}, T x_{n-1}\right)$. We also have

$$
d\left(x_{l}, T x_{l}\right) \leq d\left(x_{l}, x_{l+1}\right)+d\left(x_{l+1}, T x_{l}\right)=d\left(x_{l}, x_{l+1}\right)+d(A, B)
$$


for all $l \in \mathbb{N}$. It follows that

$$
\begin{aligned}
M\left(x_{m}, x_{n}\right) & =\max \left\{d\left(x_{m}, x_{n}\right), d\left(x_{m}, T x_{m}\right), d\left(x_{n}, T x_{n}\right)\right\} \\
& \leq \max \left\{d\left(x_{m}, x_{n}\right), d\left(x_{m}, x_{m+1}\right), d\left(x_{n}, x_{n+1}\right)\right\}+d(A, B) .
\end{aligned}
$$

Taking (2.9) into consideration, we find

$$
\lim _{m, n \rightarrow \infty} M\left(x_{m}, x_{n}\right) \leq \lim _{m, n \rightarrow \infty} d\left(x_{m}, x_{n}\right)+d(A, B) .
$$

We shall show that $\left\{x_{n}\right\}$ is a Cauchy sequence. Suppose, on the contrary, that we have

$$
\varepsilon=\limsup _{m, n \rightarrow \infty} d\left(x_{n}, x_{m}\right)>0 .
$$

Due to the triangular inequality, we have

$$
d\left(x_{n}, x_{m}\right) \leq d\left(x_{n}, x_{n+1}\right)+d\left(x_{n+1}, x_{m+1}\right)+d\left(x_{m+1}, x_{m}\right) .
$$

Regarding (1.6) and (2.12), we have

$$
\begin{aligned}
d\left(x_{n}, x_{m}\right) & \leq d\left(x_{n}, x_{n+1}\right)+d\left(T x_{n}, T x_{m}\right)+d\left(x_{m+1}, x_{m}\right) \\
& \leq d\left(x_{n}, x_{n+1}\right)+\beta\left(M\left(x_{n}, x_{m}\right)\right)\left(M\left(x_{n}, x_{m}\right)-d(A, B)\right)+d\left(x_{m+1}, x_{m}\right) .
\end{aligned}
$$

Taking (2.10), (2.13) and (2.9) into account, we derive that

$$
\begin{aligned}
\lim _{m, n \rightarrow \infty} d\left(x_{n}, x_{m}\right) & \leq \lim _{m, n \rightarrow \infty} \beta\left(M\left(x_{n}, x_{m}\right)\right) \lim _{m, n \rightarrow \infty}\left(M\left(x_{m}, x_{n}\right)-d(A, B)\right) \\
& \leq \lim _{m, n \rightarrow \infty} \beta\left(M\left(x_{n}, x_{m}\right)\right) \lim _{m, n \rightarrow \infty} d\left(x_{m}, x_{n}\right) .
\end{aligned}
$$

Owing to (2.11), we get

$$
1 \leq \lim _{m, n \rightarrow \infty} \beta\left(M\left(x_{n}, x_{m}\right)\right),
$$

which implies $\lim _{m, n \rightarrow \infty} \beta\left(M\left(x_{n}, x_{m}\right)\right)=1$. By the property of $\beta$, we have $\lim _{m, n \rightarrow \infty} M\left(x_{n}\right.$, $\left.x_{m}\right)=0$. Consequently, we have $\lim _{m, n \rightarrow \infty} d\left(x_{n}, x_{m}\right)=0$, a contradiction. Hence, we conclude that the sequence $\left\{x_{n}\right\}$ is Cauchy. Since $A$ is a closed subset of the complete metric space $(X, d)$ and $\left\{x_{n}\right\} \subset A$, and we can find $x^{*} \in A$ such that $x_{n} \rightarrow x^{*}$ as $n \rightarrow \infty$. We assert that $d\left(x^{*}, T x^{*}\right)=d(A, B)$. Suppose, on the contrary, that $d\left(x^{*}, T x^{*}\right)>d(A, B)$. First, we obtain the following inequalities:

$$
\begin{aligned}
d\left(x^{*}, T x^{*}\right) & \leq d\left(x^{*}, T x_{n}\right)+d\left(T x_{n}, T x^{*}\right) \\
& \leq d\left(x^{*}, x_{n+1}\right)+d\left(x_{n+1}, T x_{n}\right)+d\left(T x_{n}, T x^{*}\right) \\
& \leq d\left(x^{*}, x_{n+1}\right)+d(A, B)+d\left(T x_{n}, T x^{*}\right) .
\end{aligned}
$$

Letting $n \rightarrow \infty$ in the inequalities above, we conclude that

$$
d\left(x^{*}, T x^{*}\right)-d(A, B) \leq \lim _{n \rightarrow \infty} d\left(T x_{n}, T x^{*}\right) .
$$


On the other hand, we obtain

$$
d\left(x_{n}, T x_{n}\right) \leq d\left(x_{n}, x_{n+1}\right)+d\left(x_{n+1}, T x_{n}\right)=d\left(x_{n}, x_{n+1}\right)+d(A, B) .
$$

Taking limit as $n \rightarrow \infty$ in the inequality above, we find

$$
\lim _{n \rightarrow \infty} d\left(x_{n}, T x_{n}\right) \leq d(A, B) .
$$

So, we deduce that $\lim _{n \rightarrow \infty} d\left(x_{n}, T x_{n}\right)=d(A, B)$. As a consequence, we derive

$$
\lim _{n \rightarrow \infty} M\left(x_{n}, x^{*}\right)=\max \left\{\lim _{n \rightarrow \infty} d\left(x^{*}, x_{n}\right), \lim _{n \rightarrow \infty} d\left(x_{n}, T x_{n}\right), d\left(x^{*}, T x^{*}\right)\right\}=d\left(x^{*}, T x^{*}\right),
$$

and hence

$$
\lim _{n \rightarrow \infty} M\left(x_{n}, x^{*}\right)-d(A, B)=d\left(x^{*}, T x^{*}\right)-d(A, B) .
$$

Combining (1.6) and (2.14), we find

$$
\begin{aligned}
d\left(x^{*}, T x^{*}\right)-d(A, B) & \leq \lim _{n \rightarrow \infty} d\left(T x_{n}, T x^{*}\right) \\
& \leq \lim _{n \rightarrow \infty}\left[\beta\left(M\left(x_{n}, x^{*}\right)\right)\left(M\left(x_{n}, x^{*}\right)-d(A, B)\right)\right] \\
& =\lim _{n \rightarrow \infty} \beta\left(M\left(x_{n}, x^{*}\right)\right)\left(d\left(x^{*}, T x^{*}\right)-d(A, B)\right) .
\end{aligned}
$$

Since $d\left(x^{*}, T x^{*}\right)-d(A, B)>0$ together with (2.15), we get $1 \leq \lim _{n \rightarrow \infty} \beta\left(M\left(x_{n}, x^{*}\right)\right)$. Hence, we have

$$
\lim _{n \rightarrow \infty} \beta\left(M\left(x_{n}, x^{*}\right)\right)=1
$$

which yields

$$
\lim _{n \rightarrow \infty} M\left(x_{n}, x^{*}\right)=d\left(x^{*}, T x^{*}\right)=0
$$

As a result, we deduce that $d\left(x^{*}, T x^{*}\right)=0>d(A, B)$, a contradiction. So, $d\left(x^{*}, T x^{*}\right) \leq d(A, B)$ and hence $d\left(x^{*}, T x^{*}\right)=d(A, B), x^{*}$ is a best proximity point of $T$. Hence, we conclude that $T$ has a best proximity point.

We claim that the best proximity point of $T$ is unique.

Suppose, on the contrary, that $x^{*}$ and $y^{*}$ are two distinct best proximity points of $T$. Thus, we have

$$
d\left(x^{*}, T x^{*}\right)=d(A, B)=d\left(y^{*}, T y^{*}\right) .
$$

By using the $P$-property, we find

$$
d\left(x^{*}, y^{*}\right)=d\left(T x^{*}, T y^{*}\right)
$$


and

$$
\begin{aligned}
M\left(x^{*}, y^{*}\right) & =\max \left\{d\left(x^{*}, y^{*}\right), d\left(x^{*}, T x^{*}\right), d\left(y^{*}, T y^{*}\right)\right\} \\
& =\max \left\{d\left(x^{*}, y^{*}\right), d(A, B), d(A, B)\right\}=d\left(x^{*}, y^{*}\right) .
\end{aligned}
$$

Due to the fact that $T$ is a generalized Geraghty-contraction, we have

$$
\begin{aligned}
d\left(x^{*}, y^{*}\right) & =d\left(T x^{*}, T y^{*}\right) \\
& \leq \beta\left(M\left(x^{*}, y^{*}\right)\right)\left(M\left(x^{*}, y^{*}\right)-d(A, B)\right) \\
& =\beta\left(d\left(x^{*}, y^{*}\right)\right)\left(d\left(x^{*}, y^{*}\right)-d(A, B)\right) \\
& \leq \beta\left(d\left(x^{*}, y^{*}\right)\right) d\left(x^{*}, y^{*}\right)<d\left(x^{*}, y^{*}\right),
\end{aligned}
$$

a contradiction. This completes the proof.

Remark 9 Let $(X, d)$ be a metric space and $A$ be any nonempty subset of $X$. It is evident that a pair $(A, A)$ satisfies the $P$-property.

Corollary 10 Suppose that $(X, d)$ is a complete metric space and $A$ is a nonempty closed subset of $X$. If a self-mapping $T: A \rightarrow A$ is a generalized Geraghty-contraction, then it has a unique fixed point.

Proof Taking Remark 9 into consideration, we conclude the desired result by applying Theorem 8 with $A=B$.

In order to illustrate our main result, we present the following example.

Example 11 Suppose that $X=\mathbb{R}^{2}$ with the metric

$$
d\left((x, y),\left(x^{\prime}, y^{\prime}\right)\right)=\max \left\{\left|x-x^{\prime}\right|,\left|y-y^{\prime}\right|\right\}
$$

and consider the closed subsets

$$
\begin{aligned}
& A=\{(x, 0): 0 \leq x \leq 1\}, \\
& B=\{(x, 0):-1 \leq x \leq 0\},
\end{aligned}
$$

and let $T: A \rightarrow B$ be the mapping defined by

$$
T((x, 0))=\left(\frac{-x}{1+x}, 0\right) .
$$

Since $d(A, B)=0$, the pair $(A, B)$ has the $P$-property.

Notice that $A_{0}=(0,0)$ and $B_{0}=(0,0)$ and $T\left(A_{0}\right) \subseteq B_{0}$.

Moreover,

$$
d\left(T(x, 0), T\left(x^{\prime}, 0\right)\right)=d\left(\left(\frac{-x}{1+x}, 0\right),\left(\frac{-x^{\prime}}{1+x^{\prime}}, 0\right)\right)=\left|\frac{-x}{1+x}+\frac{x^{\prime}}{1+x^{\prime}}\right|=\frac{\left|x^{\prime}-x\right|}{(1+x)\left(1+x^{\prime}\right)}
$$


and, as $(1+x)\left(1+x^{\prime}\right) \geq 1+\left|x-x^{\prime}\right|$, we have

$$
d\left(T(x, 0), T\left(x^{\prime}, 0\right)\right)=\frac{\left|x^{\prime}-x\right|}{(1+x)\left(1+x^{\prime}\right)} \leq \frac{\left|x^{\prime}-x\right|}{1+\left|x-x^{\prime}\right|}=\beta\left(\left|x-x^{\prime}\right|\right)=\beta\left(d\left((x, 0),\left(x^{\prime}, 0\right)\right)\right),
$$

where $\beta:[0, \infty) \rightarrow[0,1)$ is defined as $\beta(t)=\frac{t}{1+t}$.

Notice that $\beta$ is nondecreasing since $\beta^{\prime}(t)=\frac{1}{(1+t)^{2}}$.

Therefore,

$$
\begin{aligned}
d\left(T(x, 0), T\left(x^{\prime}, 0\right)\right) & \leq \beta\left(d\left((x, 0),\left(x^{\prime}, 0\right)\right)\right) \leq \beta\left(M\left((x, 0),\left(x^{\prime}, 0\right)\right)\right) \\
& =\frac{\beta\left(M\left((x, 0),\left(x^{\prime}, 0\right)\right)\right)}{M\left((x, 0),\left(x^{\prime}, 0\right)\right)} \cdot M\left((x, 0),\left(x^{\prime}, 0\right)\right)
\end{aligned}
$$

and it is easily seen that the function $\gamma(t)=\frac{\beta(t)}{t}=\frac{1}{1+t}$ belongs to $F$.

Therefore, since the assumptions of Theorem 8 are satisfied, by Theorem 8 there exists a unique $\left(x^{*}, 0\right) \in A$ such that

$$
d\left(\left(x^{*}, 0\right), T\left(x^{*}, 0\right)\right)=0=d(A, B) .
$$

The point $\left(x^{*}, 0\right) \in A$ is $(0,0) \in A$.

\section{Competing interests}

The authors declare that they have no competing interests.

\section{Authors' contributions}

All authors read and approved the final manuscript.

\section{Author details}

'Department of Mathematics, Faculty of Science and Arts, Amasya University, Amasya, 06500, Turkey. ${ }^{2}$ Department of Mathematics, Atilim University, Incek, Ankara 06836, Turkey. ${ }^{3}$ Department of Mathematics, University of Las Palmas de Gran Canaria, Campus Universitario de Tafira, Las Palmas de Gran Canaria, 35017, Spain.

Received: 6 February 2013 Accepted: 22 May 2013 Published: 6 June 2013

\section{References}

1. Geraghty, M: On contractive mappings. Proc. Am. Math. Soc. 40, 604-608 (1973)

2. Caballero, J, Harjani, J, Sadarangani, K: A best proximity point theorem for Geraghty-contractions. Fixed Point Theory Appl. 2012, $231(2012)$

3. Eldred, AA, Veeramani, P: Existence and convergence of best proximity points. J. Math. Anal. Appl. 323, $1001-1006$ (2006)

4. Anuradha, J, Veeramani, P: Proximal pointwise contraction. Topol. Appl. 156, 2942-2948 (2009)

5. Markin, J, Shahzad, N: Best approximation theorems for nonexpansive and condensing mappings in hyperconvex spaces. Nonlinear Anal. 70, 2435-2441 (2009)

6. Basha, SS, Veeramani, P: Best proximity pair theorems for multifunctions with open fibres. J. Approx. Theory 103, 119-129 (2000)

7. Raj, VS, Veeramani, P: Best proximity pair theorems for relatively nonexpansive mappings. Appl. Gen. Topol. 10, 21-28 (2009)

8. Al-Thagafi, MA, Shahzad, N: Convergence and existence results for best proximity points. Nonlinear Anal. 70, 3665-3671 (2009)

9. Kirk, WA, Reich, S, Veeramani, P: Proximinal retracts and best proximity pair theorems. Numer. Funct. Anal. Optim. 24, 851-862 (2003)

10. Raj, VS: A best proximity theorem for weakly contractive non-self mappings. Nonlinear Anal. 74, 4804-4808 (2011)

11. Raj, VS: Banach's contraction principle for non-self mappings. Preprint

12. Karapınar, E: Best proximity points of cyclic mappings. Appl. Math. Lett. 25(11), 1761-1766 (2012)

13. Karapınar, E, Erhan, ÝM: Best proximity point on different type contractions. Appl. Math. Inf. Sci. 3(3), 342-353 (2011)

14. Karapınar, E: Best proximity points of Kannan type cyclic weak $\phi$-contractions in ordered metric spaces. An. Stiint. Univ. Ovidius Constanta 20(3), 51-64 (2012)

15. Mongkolkeha, C, Kumam, P: Best proximity point theorems for generalized cyclic contractions in ordered metric spaces. J. Optim. Theory Appl. 155, 215-226 (2012) 
16. Mongkolkeha, C, Kumam, P: Some common best proximity points for proximity commuting mappings. Optim. Lett. (2012, in press). doi:10.1007/s11590-012-0525-1

17. Jleli, M, Samet, B: Best proximity points for $\alpha$ - $\psi$-proximal contractive type mappings and applications. Bull. Sci. Math (2013). doi:10.1016/j.bulsci.2013.02.003

18. Mongkolkeha, C, Cho, YJ, Kumam, P: Best proximity points for generalized proximal C-contraction mappings in metric spaces with partial orders. J. Inequal. Appl. 2013, 94 (2013)

19. De la Sen, M: Fixed point and best proximity theorems under two classes of integral-type contractive conditions in uniform metric spaces. Fixed Point Theory Appl. 2010, Article ID 510974 (2010)

doi:10.1186/1029-242X-2013-286

Cite this article as: Bilgili et al.: A generalization for the best proximity point of Geraghty-contractions. Journal of Inequalities and Applications 2013 2013:286.

Submit your manuscript to a SpringerOpen ${ }^{\odot}$ journal and benefit from:

- Convenient online submission

- Rigorous peer review

- Immediate publication on acceptance

- Open access: articles freely available online

- High visibility within the field

- Retaining the copyright to your article

Submit your next manuscript at $>$ springeropen.com 